\title{
Correction to: Estimating the Potential of Archaeo-historical Data in the Definition of Geomorphosites and Geo-educational Itineraries in the Central Po Plain ( $\mathrm{N}$ Italy)
}

\author{
Filippo Brandolini ${ }^{1} \cdot$ Mauro Cremaschi $^{1} \cdot$ Manuela Pelfini $^{1}$
}

Published online: 17 June 2019

(C) The European Association for Conservation of the Geological Heritage 2019

\section{Correction to: Geoheritage}

https://doi.org/10.1007/s12371-019-00370-5

The original version of this article unfortunately contained a mistake. The authors' family names/first names have been inverted. The correct author names are listed above.

The online version of the original article can be found at https://doi.org/ $10.1007 / \mathrm{s} 12371-019-00370-5$

Filippo Brandolini

fibrandolini@gmail.com

Earth Sciences Department "Ardito Desio", Università degli Studi di Milano, Via Luigi Mangiagalli, 34, 20133 Milan, MI, Italy 